

\title{
Integration of high seeding densities and criss cross row planting pattern suppresses weeds and increases grain yield of spring wheat
}

Authors Info

I. Hussain', E.A. Khan', G. Hassan ${ }^{2, *}$, J. Gul ${ }^{3}$, M. Ozturk, H. Alharby ${ }^{5}$, K.R. Hakeem $^{5}$ and S. Alamri ${ }^{6}$

'Department of Agronomy, Faculty of Agriculture, Gomal University, Dera Ismail Khan, 29050, Pakistan

${ }^{2}$ Department of Agriculture, Shaheed Benazir Bhutto University, Sheringal Dir Upper, 18050, Pakistan

${ }^{3}$ Department of Biotechnology Shaheed Benazir Bhutto University, Sheringal Dir Upper, 18050, Pakistan

${ }^{4}$ Botany Department and Center for Environmental Studies, Ege University, 35100 , Izmir, Turkey

${ }^{5}$ Department of Biological Sciences, Faculty of Science, King Abdulaziz University, Jeddah, 21589, Saudi Arabia ${ }^{6}$ Department of Botany and Microbiology, College of Science, King Saud University, Riyadh, 2455, Saudi Arabia

*Corresponding Author Email : hassanpk.2000pk@yahoo.com

Key words

Criss cross,

Integrated weed management,

Smothering effect,

Yield components

Publication Info

Paper received : 15.11 .2016

Revised received : 22.06 .2017

Accepted : 27.06.2017

\section{Abstract}

Aim : Eco-friendly and sustainable weed management tactics are advocated by weed managers worldwide. In order to develop such a technology, an experiment was undertaken at Agronomic Research Area of the Faculty of Agriculture, Gomal University, Dera Ismail Khan, Khyber Pakhtunkhwa province, Pakistan during rabi season.

Methodology : A 2-factor experiment was laid out in a randomized complete block design with split plot arrangement with the planting patterns (line and criss cross sowings) assigned to main plots and seed rates $(50,100,150,200$ $\mathrm{kg} \mathrm{ha}^{-1}$ ) of wheat kept into sub plots.

Results : Weed density and biomass at harvest were 28 and $33 \%$, lesser in a criss cross as compared to line sowing. Weed suppression was inversely and grain yield was directly proportional to seeding rates. The highest grain yield $\left(6.9 \mathrm{t} \mathrm{ha}^{-1}\right)$ was obtained from the interaction of $200 \mathrm{~kg} \mathrm{ha}^{-1}$ seed rate under criss cross planting.

Interpretation : Regardless of planting pattern, $37 \%$ higher grain yield was harvested at the highest rate $\left(200 \mathrm{~kg} \mathrm{ha}^{-1}\right)$ as compared to the lowest $(50 \mathrm{~kg}$ $\mathrm{ha}^{-1}$ ) seed rate. Thus, integration of denser crop and uniform stand via criss cross pattern planting in small grains can reduce the pollution of herbicides and energy cost on weed management.

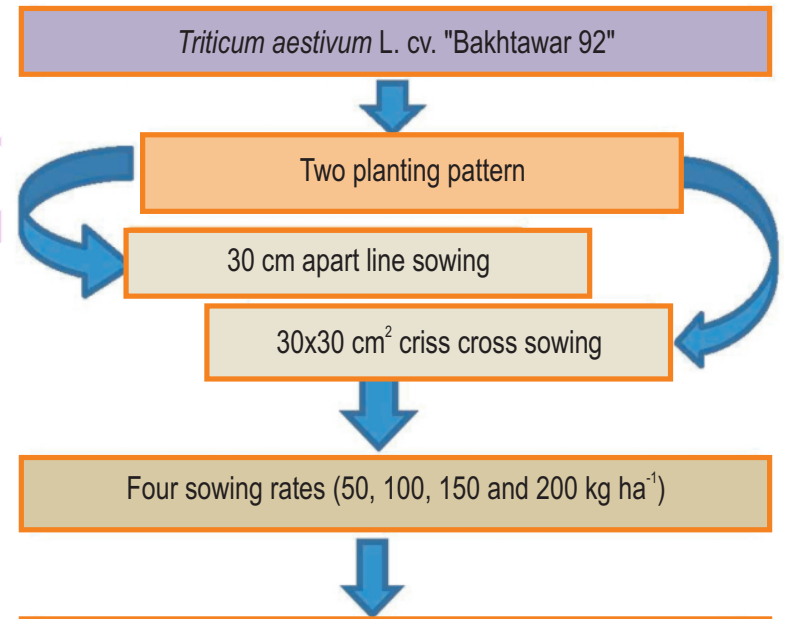

- Weed density $\left(\mathrm{m}^{-2}\right) 30$ days after germination

- Weed density $\left(\mathrm{m}^{-2}\right)$ at harvest

- Biomass of weeds $\left(\mathrm{g} \mathrm{m}^{-2}\right)$ at harvest

- Plant height at maturity $(\mathrm{cm})$

- Number of tillers o whest $\mathrm{m}^{-2}$

- No. of grains per spike

- Biological yield $\left(\mathrm{kg} \mathrm{ha}^{-1}\right)$

- Grain yield (t ha-1)

- Harvest index (\%)

Cross-cross drill sowing $\left(30 \times 30 \mathrm{~cm}^{2}\right)$ proved to be a promising method against weed growth and development when wheat was planted at the highest seed rate $\left(200 \mathrm{~kg} \mathrm{ha}^{-1}\right)$ 


\section{Introduction}

Wheat is the leading food grain crop of Pakistan like elsewhere in the world, occupying the largest area (66\%) among all cultivated crops in the country. Wheat contributes $10 \%$ to the value addition in agriculture and $2.1 \%$ to GDP (Ashraf et al., 2012; Hakeem et al., 2013). Wheat was planted on 9.18 million ha with a production of 25.478 million tons during 2014-15. It fulfills $95 \%$ food requirement of the country (Anonymous, 2015).

Wheat yield per unit area in the country is very low due to numerous production constrains including poor quality seed, inadequacy of irrigation, non-judicious use of fertilizers, incidence of diseases, lack of high yielding adapted cultivars and exceeding all is the infestation of weeds (Ghaffar et al., 2013).

Weeds are the plants whose virtues have not been discovered so far (Ross and Lembi, 1985). Weeds compete with the crop plants for available moisture, nutrients, space and solar radiation. The major weeds infesting the experimental site are wild oats (Avena fatua L.), littleseed canary grass (Phalaris minor Retz.), curly dock (Rumex crispus L.), field bindweed (Convolvulus arvensis L.), creeping thistle (Cirsium arvense L.), burclover (Medicago denticulate Willd.) and Indian sweetclover (Melilotus parviflora L.).

Weeds inflict greater than $17 \%$ losses in crop yield and deteriorate the quality of farm produce, consequently reducing the market value of crops particularly wheat. Whereas, Singh et al. (2013) evaluated $15-40 \%$ loss in yield based on diversity and intensity of infesting flora.

The green revolution has increased the yields for a while, but with the indiscriminate use of chemicals caused deleterious effects in human beings and animals. Global environmental cautiousness and development of resistance to herbicides in weeds has warranted the focus on ecofriendly cultural control of weeds for sustainability (Weiner et al., 2001). Mechanical control is also an alternative to chemical control, but it also involves an input of energy, soil compaction and crop injury. Panwar et al. (1995), Singh and Singh (1996) and Pandey and Kumar (2005) stated that cross-row sowing of wheat significantly reduced the dry weight of weed biomass. In an another study, Xue et al. (2011) evaluated higher biomass and yield as seeding rate increased up to $65 \mathrm{~kg} \mathrm{ha}^{-1}$ due to more spikes per $\mathrm{m}^{2}$ but fewer seeds per spike. Khan et al. (2000) and Hassan and Khan (2007) reported an increased plant population to be used as a tool in weed management in many crops including wheat. The use of dense crop population, narrow row width and cross drill sowing technique are some of the known management tactics to overcome weed competition (Weiner et al., 2001; Kristensen et al., 2008; Korres and Froud-Williams, 2002).

There is, however, a controversy among scientists about the seed rate and method of sowing both affecting wheat yield and yield contributing factors (Kristensen et al., 2008; Ahmed et al., 2014). Whereas, Singh et al. (2013) also advised thorough sitespecific verification of integrated measures of weed management. Keeping in view the weeds as a major yield constraint and smothering effect of high density wheat planted in varying patterns in an Integrated Weed Management (IWM) tactic, the present study was carried out under the agro-climatic conditions of Dera Ismail Khan, Pakistan.

\section{Materials and Methods}

An experiment was conducted in the Agronomic Research Area of Faculty of Agriculture, Gomal University, Dera Ismail Khan $\left(31.82^{\circ} \mathrm{N}, 70.92^{\circ} \mathrm{E}\right.$ and $173 \mathrm{~m}$ asl), Khyber Pakhtunkhwa, Pakistan during Rabi (winter) season using wheat cultivar "Bakhtawar 92". Two planting patters (30 cm apart line sowing and $30 \times 30 \mathrm{~cm}^{2}$ criss cross sowing) and four sowing rates $\left(50,100,150\right.$ and $\left.200 \mathrm{~kg} \mathrm{ha}^{-1}\right)$ were evaluated for their effect on weed dynamics and grain yield and its associated traits of wheat. The experiment was laid out in split plot design having sown methods in the main plants and seed rate in sub-plots. Each subplot was replicated thrice.

Experimental site and cultural practices : The experimental soil of site was clay loam in texture having $15 \%$ sand, $40 \%$ silt, $55 \%$ clay, pH 8.5, 7 ppm $\mathrm{P}_{2} \mathrm{O}_{5}, 0.77 \%$ organic matter, $0.034 \% \mathrm{~N}$ and $100 \mathrm{ppm} \mathrm{K} \mathrm{K}_{2} \mathrm{O}$. First irrigation was applied at the early seeding stage, $2^{\text {nd }}$ at tillering, $3^{\text {rd }}$ at booting, $4^{\text {th }}$ at earing and the last at dough stage of wheat. Whole phosphorus $\mathrm{P}_{2} \mathrm{O}_{5} @ 60 \mathrm{~kg}$ ha-1was used at the time of sowing. Nitrogen was applied @ $150 \mathrm{~kg} \mathrm{ha}^{-1}$, half at the time of sowing, while the remaining half dose with $1^{\text {st }}$ irrigation. Urea and single super phosphate were used as a source of nitrogen and phosphorus, respectively.

Metrology of the experimental site : During the course of the experiment, the study area received $169 \mathrm{~mm}$ rainfall. The mean ambient temperature during the growing season ranged from $18^{\circ} \mathrm{C}$ in November to $14^{\circ} \mathrm{C}$ in December and $18^{\circ} \mathrm{C}$ in March to $25^{\circ} \mathrm{C}$ in April. The climate of the site is semi arid with an ample supply of canal irrigation water.

Data collection and analyses : During the duration of experiment, data were recorded on weed dynamics (weed density 30 days after germination and at harvest, weed biomass $g$ $\mathrm{m}^{-2}$ ) and morphological and agronomic data of wheat (crop height, tillers plant ${ }^{-1}$, grains spike ${ }^{-1}$, biological and grain yield $\mathrm{kg} \mathrm{ha}^{-1}$ and harvest index). The data collected for individual parameters were subjected to analysis of variance technique and the significant level of means were determined by Duncan's Multiple Range Test (DMRT) (Steel et al., 1997). Further, the data for weed density (30 days after germination and at harvest), weed biomass and grain yield against seed rates were also subjected to linear regression analysis for establishing an association between planting density and weed dynamics and grain yield. 
Table 1 : Effect of sowing patterns and seed rates on density and biomass of weeds

\begin{tabular}{|c|c|c|c|c|c|}
\hline \multicolumn{6}{|c|}{ Weeds density $\left(\mathrm{m}^{-2}\right) 30$ days after germination } \\
\hline \multirow[t]{2}{*}{ Methods of s owing } & \multicolumn{5}{|c|}{ Seed rate $\left(\mathrm{kg} \mathrm{ha}^{-1}\right)$} \\
\hline & 50 & 100 & 150 & 200 & Means \\
\hline Cross drill $30 \times 30 \mathrm{~cm}^{2}$ & $28.50^{\mathrm{NS}}$ & 26.7 & 25.0 & 22.0 & $25.55^{\mathrm{NS}}$ \\
\hline Line sowing $30 \mathrm{~cm}$ apart & 29.25 & 28.0 & 24.7 & 23.2 & $26.2^{9}$ \\
\hline Means & $28.88^{\mathrm{a}}$ & $27.35^{\mathrm{a}}$ & $24.5^{\mathrm{ab}}$ & $22.6^{b}$ & \\
\hline \multicolumn{6}{|c|}{ Weeds density $\left(\mathrm{m}^{-2}\right)$ at harvest of wheat } \\
\hline Cross drill $30 \times 30 \mathrm{~cm}^{2}$ & $80.25^{c \dagger}$ & $74.7^{\mathrm{dd}}$ & $63.5^{\mathrm{d}}$ & $56.0^{\circ}$ & $68.61^{b}$ \\
\hline Line sowing $30 \mathrm{~cm}$ apart & $113.2^{\mathrm{a}}$ & $91.5^{b}$ & $83.7^{\circ}$ & $63.2^{d}$ & $87.9^{\mathrm{a}}$ \\
\hline Means & $96.73^{\mathrm{a}}$ & $83.1^{\mathrm{b}}$ & $73.6^{c}$ & $59.6^{d}$ & \\
\hline \multicolumn{6}{|c|}{ Weed biomass $\left(\mathrm{m}^{-2}\right)$ at harvest of wheat } \\
\hline Cross drill $30 \times 30 \mathrm{~cm}^{2}$ & $29.50^{c}$ & $29.20^{c}$ & $24.31^{d}$ & $15.72^{\mathrm{e}}$ & $24.68^{b}$ \\
\hline Line sowing $30 \mathrm{~cm}$ apart & $45.2^{\mathrm{a}}$ & $38.1^{\mathrm{b}}$ & $28.15^{\mathrm{c}}$ & $19.2^{\text {de }}$ & $32.66^{a}$ \\
\hline Means & $37.35^{\mathrm{a}}$ & $33.65^{b}$ & $26.23^{c}$ & $17.46^{d}$ & \\
\hline
\end{tabular}

NS= Non significant $(P>0.05)$; † Means not sharing a letter in common in the respective category, differ significantly at $P<0.05$ by Duncan's Multiple Range Test

Table 2 : Effect of sowing patterns and seed rates on some morphological and agronomic traits of wheat

\begin{tabular}{|c|c|c|c|c|c|}
\hline \multicolumn{6}{|c|}{ Seed rate $\left(\mathrm{kg} \mathrm{ha}^{-1}\right)$} \\
\hline Sowing pattern & 50 & 100 & 150 & 200 & Means \\
\hline \multicolumn{6}{|c|}{ Final Plant height $(\mathrm{cm})$ of wheat } \\
\hline Cross drill $30 \times 30 \mathrm{~cm}^{2}$ & $75.70^{\text {NS }}$ & 81.8 & 84.7 & 89.62 & $82.96^{\text {NS }}$ \\
\hline Line sowing $30 \mathrm{~cm}$ apart & 76.9 & 77.2 & 84.5 & 90.50 & 82.28 \\
\hline Means & $76.3 c$ & $79.5^{\mathrm{bc}}$ & $84.6^{\mathrm{ab}}$ & $90.06^{\mathrm{a}}$ & \\
\hline \multicolumn{6}{|l|}{ No. of tillers $\mathrm{m}^{-2}$} \\
\hline Cross drill $30 \times 30 \mathrm{~cm}^{2}$ & $242^{\mathrm{e}}$ & $285.0^{d}$ & $405.2^{b}$ & $488.2^{\mathrm{a}}$ & $355.1^{\mathrm{NS}}$ \\
\hline Line sowing $30 \mathrm{~cm}$ apart & $240.8^{c}$ & $328.6^{c}$ & $382.6^{c}$ & $415.3^{c}$ & 341.75 \\
\hline Means & $241.4^{d}$ & $306^{c}$ & $393.9^{b}$ & $451.8^{\mathrm{a}}$ & \\
\hline \multicolumn{6}{|l|}{ No. of grains spike ${ }^{-1}$} \\
\hline Cross drill $30 \times 30 \mathrm{~cm}^{2}$ & $65.2^{\text {NS }}$ & 61.5 & 61.2 & 59.3 & $62.05^{\mathrm{NS}}$ \\
\hline Line sowing $30 \mathrm{~cm}$ apart & 63.5 & 56.2 & 62.1 & 59.2 & 60.25 \\
\hline Means & $64.85^{\mathrm{NS}}$ & 58.85 & 61.65 & 59.25 & \\
\hline \multicolumn{6}{|l|}{1000 grain wt. of wheat $(\mathrm{g})$} \\
\hline Cross drill $30 \times 30 \mathrm{~cm}^{2}$ & $37.5^{\mathrm{NS}}$ & 36.2 & 35.2 & 35.0 & $35.98^{\text {NS }}$ \\
\hline Line sowing $30 \mathrm{~cm}$ apart & 38.8 & 38.7 & 35.5 & 35.7 & 37.18 \\
\hline Means & $38.15^{\mathrm{NS}}$ & 37.45 & 35.35 & 35.35 & \\
\hline \multicolumn{6}{|c|}{ Biological yield of wheat $\left(\mathrm{t} \mathrm{ha} \mathrm{a}^{-1}\right)$} \\
\hline Cross drill $30 \times 30 \mathrm{~cm}^{2}$ & $9.8 c^{\dagger}$ & $10.4^{\mathrm{bc}}$ & $11.34^{b}$ & $13.60^{\mathrm{a}}$ & $11.3^{\mathrm{NS}}$ \\
\hline Line sowing $30 \mathrm{~cm}$ apart & $8.3^{\mathrm{c}}$ & $10.00^{\mathrm{bc}}$ & $11.30^{\mathrm{b}}$ & $12.20^{\mathrm{ab}}$ & 10.45 \\
\hline Means & $9.05^{\mathrm{c}}$ & $10.2^{\mathrm{bc}}$ & $11.35^{\mathrm{ab}}$ & $12.90^{\mathrm{a}}$ & \\
\hline \multicolumn{6}{|l|}{ Grain yield of wheat $\left(\mathrm{tha}^{-1}\right)$} \\
\hline Cross drill $30 \times 30 \mathrm{~cm}^{2}$ & $4.5^{c}$ & $5.0^{\mathrm{ab}}$ & $6.2^{\mathrm{a}}$ & $6.9^{\mathrm{a}}$ & $5.65^{\mathrm{a}}$ \\
\hline Line sowing $30 \mathrm{~cm}$ apart & $4.4^{\circ}$ & $4.8^{\mathrm{C}}$ & $4.7^{\mathrm{c}}$ & $5.3^{\mathrm{ab}}$ & $4.8^{b}$ \\
\hline Means & $4.45^{\mathrm{b}}$ & $4.9^{\mathrm{b}}$ & $5.45^{\mathrm{ab}}$ & $6.1^{\mathrm{a}}$ & \\
\hline \multicolumn{6}{|l|}{ Harvest Index (\%) } \\
\hline Cross drill $30 \times 30 \mathrm{~cm}^{2}$ & $46.0^{\mathrm{NS}}$ & 48 & 54.4 & 50.74 & $49.79^{\text {NS }}$ \\
\hline Line sowing $30 \mathrm{~cm}$ apart $\mathrm{r}$ & 53.0 & 48 & 42.0 & 43.4 & 46.6 \\
\hline Means & $49.5^{\mathrm{NS}}$ & 48 & 48.2 & 47.07 & \\
\hline
\end{tabular}

NS = Non significant $(P>0.05)$; $†$ Means not sharing a letter in common in the respective category, differ significantly at $P_{0.01}$ by Duncan's Multiple Range Test 


\section{Results and Discussion}

The statistical analysis of data in Table 1 exhibit the main effects of planting parameters, and their interaction with seed rate for weeds density at 30 days after sowing were non significant, while significant $(P<0.05)$ differences were depicted for seeding rates. Although numerically non-significant, slightly lower number of weeds were counted for cross rows. Suppressing trend in cross row sowing pattern could be due the reason that bi-directional row offered spatial uniformity of the crop for effective competition with weeds at earlier phonological stages (Kristensen et al., 2008). Khan et al. (2000) also confirmed our results. Four seed rates showed significant differences on weed density. With the increased seeding rates, weed density becomes thinner. It means that the higher seed rates of wheat can be used to suppress weeds. These results are corroborated by the earlier work of Khan et al. (2000), Hassan and Khan (2007) and Khan et al. (2007). They found higher seed rates established more competitive wheat crop with weeds. The interaction between sowing methods and seed rates reveal that weed densities decreased gradually with increasing seed rate either in line sowing or cross drill method. It can be concluded from these results that increased plant population can play a decisive role in weed management. Linear regression (Fig. 1) on weed density per $\mathrm{m}^{2} 30$ days after germination exhibited a strong negative relationship $\left(R^{2}=99 \%\right)$. Hassan and Khan (2007) and Khan et al. (2008) suppressed wild oats with an increased seeding density of wheat. Singh et al. (2013) stated that cross drill method (bidirectional drill) reduces compaction, prepares the seed bed well, ensures that crop seed must be placed in an ideal growing environment, enables the crop to emerge as early as possible and suppresses weed seed to germinate and grow.

The statistical analysis of data revealed that the main effects and interaction of both factors studied were significant $(P<0.05)$. Weed densities observed in criss cross sowing method at the time of harvest was significantly lesser than the line sowing method (Table 1). Further, it also revealed that there was a decline in weed plant population significantly as the seed rate increased. Even at $50 \mathrm{~kg} \mathrm{ha}^{-1}$, the criss cross method possessed $41 \%$ lesser number of weeds and the difference persisted across all the seeding rates. The regression analysis also established a strong inverse relationship $\left(R^{2}=99 \%\right)$ between seed rates and weed density at harvest (Fig. 2). The suppressive effect of seeds and criss cross planting can be attributed to uniform crop distribution and earlier space capture. Khan et al. $(2000,2007)$ also reported that increased wheat seed rates dwindle weed density linearly. Ghaffar et al. (2013) conducted an experiment on optimizing seed rate and row spacing for different wheat cultivars and their results indicated that with the application of higher seed rates weeds density was lesser. Singh et al. (2013) argued about the significance of cross drill sowing method in weed management. They reported that due to higher number of wheat tillers in cross drill method resulted in enhanced competitive ability of weeds.
Pandey and Kumar (2005) also ascertained that criss cross sowing significantly reduced weed count and weed dry biomass than broadcasting. Fahad et al. (2015) contemplated lesser weed growth in narrow row spacing $(11-\mathrm{cm})$ of wheat as compared with wider rows (15 and $23-\mathrm{cm}$ ).

Main effects for planting pattern and seeding rate and their interaction were statistically significant $(P<0.05)$. The perusal of data in Table 1 revealed that the heavier biomass of weeds was recorded in line sowing $(32.66 \mathrm{~g})$. While for the seeding rates, the highest weed biomass was recorded at $50 \mathrm{~kg}$ ha $^{-1}(37.35 \mathrm{~g})$, while lowest biomass ( $17.46 \mathrm{~g}$ ) was recorded in 200 $\mathrm{kg} \mathrm{ha}^{-1}$, which was $53 \%$ lower than the least seeding rate. In interaction, all the treatments involving criss cross sowing possessed lower biomass as compared to the corresponding values involving line sowing (Table 1). The minimum weed biomass was produced in $200 \mathrm{~kg} \mathrm{ha}^{-1} \mathrm{x}$ criss cross seeding (15.72 g). The strongest relationship $\left(R^{2}\right)$ of seeding rates and weed biomass was also deciphered by regressing weed biomass with the seed rates (Fig. 3). These results are in a great analogy with the previous findings of Xue et al. (2011) who were of the opinion that biomass and yield increase were directly proportional to seeding rate of wheat as seeding rate increased up to $65 \mathrm{~kg} \mathrm{ha}^{-1}$. Higher seeding rates resulted in more spikes per $\mathrm{m}^{2}$ but less seeds per spike ${ }^{1}$. Khan et al. (2007) and Ghaffar et al. (2013) also advocated that different seeding rates and sowing methods suppressed the weed number and biomass significantly. Competitive cultivars with higher seed rate may therefore be an important component of integrated weed management strategies (Mahajan et al., 2013). Likewise, Marwat et al. (2011) evaluated 705 vs. $572 \mathrm{~kg} \mathrm{ha}^{-1}$ biomass of weeds in 150 as compared to 100 $\mathrm{kg} \mathrm{ha}^{-1}$ seeding rate in wheat. Singh and Singh (1996), Pandey et al. (2009) and Singh et al. (2013) concluded from their experiments that bi-directional (cross-drill) sowing of wheat registered significantly lesser biomass of weeds as compared to undirected sowing. Similarly, Brac and Walia (2009) reported that if the condition is ideal, higher than the normal seeding rate can increase crop competitiveness and yield. A seeding rate higher than $150 \mathrm{~kg} \mathrm{ha}^{-1}$ reduced the biomass and dry matter accumulation of weeds together with increased grain yield of wheat.

The data exhibited that the main effects of two factors studied as well as their interaction was non significant statistically (Table 2). Minimum plant height $(76.3 \mathrm{~cm}$ ) was recorded when the crop was seeded at $50 \mathrm{~kg} \mathrm{ha-1}$. Maximum plant height was recorded at seed rate $200 \mathrm{~kg} \mathrm{ha}^{-1}$. Plant height increased as amount of seed rate increased, which might be due to competition of plants for resources like sunlight. In most of the studies plant height observed strictly under genetic control and seldom influenced by the environment. However, Ayaz et al. (1999) evaluated in their studies that wheat height increased proportionately with the seeding rates. Ali et al. (2010) also received taller crop under wider rows as compared to the narrow 


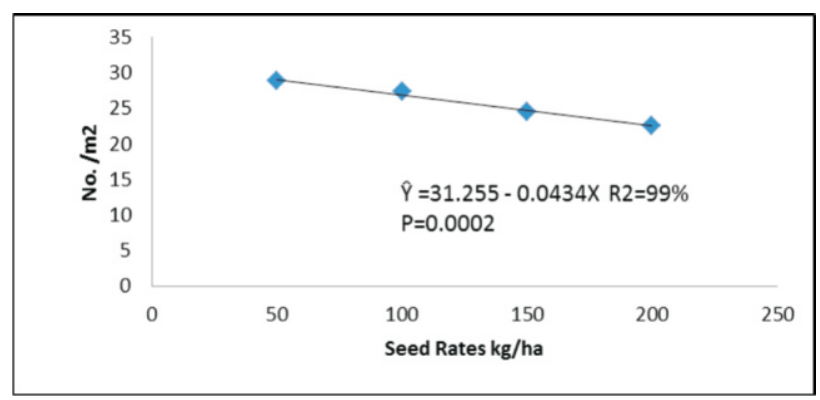

Fig. 1 : Relationship of weed density 30 days after germination vs. seed rates

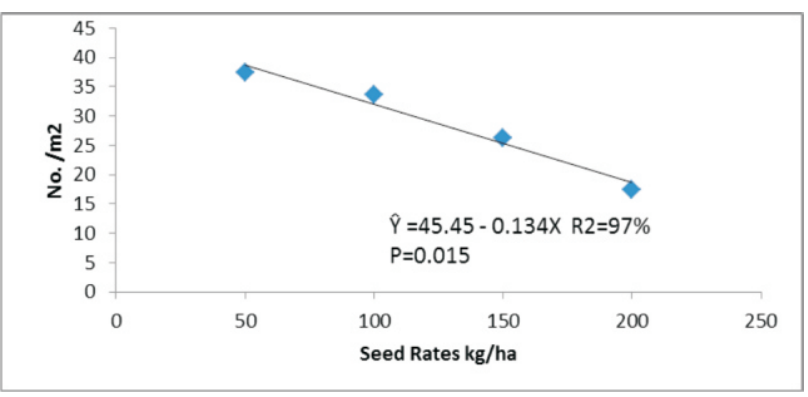

Fig. 3 : Relationship of weed biomass at harvesting of wheat vs. seed rates

rows of wheat.

The data on the effect of seed rates and sowing methods on number of tillers per $\mathrm{m}^{2}$ of wheat recorded is presented in Table 2 , which indicated that seed rates and their interaction with sowing methods had a significant effect on the number of tillers per $\mathrm{m}^{2}$, while sowing patterns had non-significant effect. Number of tillers increased with every incremental step of seed rate due to increased number of established seedlings. The criss cross method of sowing gave more tillers per $\mathrm{m}^{2}$ as compared to line sowing, but could not attain the expected level of statistical significance. Increased number of tillers per $\mathrm{m}^{2}$ was the highest (488.2) when the crop was seeded @200 kg ha ${ }^{-1}$ under criss cross regime. The lesser number of tillers across the line sowing could be ascribed to self thinning rule which states plant populations growing at high densities undergo density-dependent mortality or self-thinning (White, 1981). Under criss cross sowing there was even distribution of crop plants, hence escaped mortality as against line sowing. Moreover, there were fewer weeds under criss cross, which could have also contributed to survival and higher stand. Tunio et al. (2004) found an increase in tillers per $\mathrm{m}^{2}$ at higher seed rates, established better crop and good competition with weeds. Ayaz et al. (1999) also observed increased tillers per $\mathrm{m}^{2}$ with successive increase in the seeding rate, but tillers per seedling decreased with increase in seed rate. Kaur et al. (2014) also observed more tiller $\mathrm{m}^{-2}$ in cross-drill

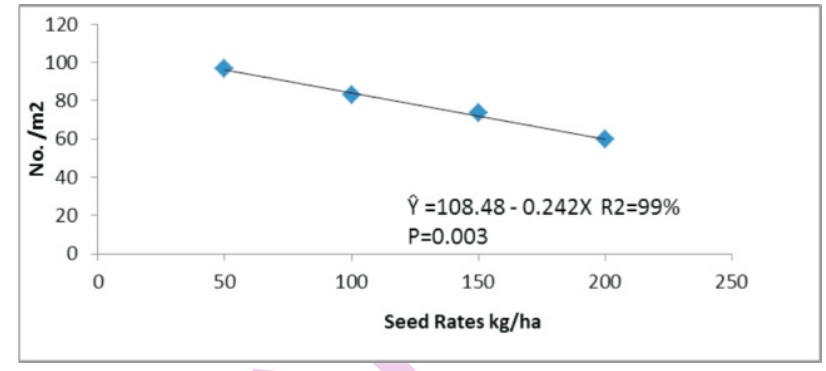

Fig. 2 : Relatioship of weed density at harvesting of wheat vs. seed ratesa

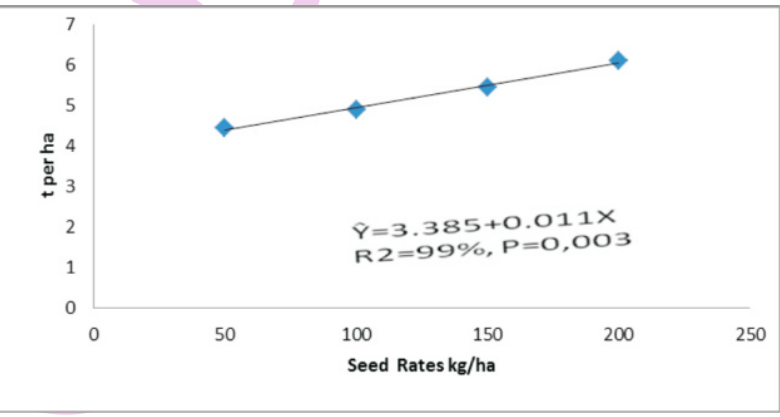

Fig. 4 : Regression of grain yield of wheat vs. seed rates

method as compared to normal sowing methods.

The number of grains per spike is a good indicator of ultimate realized yield of wheat. The effect of four seed rates, two sowing methods and their interaction were statistically nonsignificant (Table 2). Thus, obviously this trait is strictly under genetic control and not influenced by the environment. There has been dispersion in data, but it could not achieve significance level. It may be due to the genetic makeup of this cultivar. Numerically more number of grains per spike were found at the lowest seed rate of $50 \mathrm{~kg} \mathrm{ha}^{-1}$, while minimum weight was observed at $200 \mathrm{~kg}$ $\mathrm{ha}^{-1}$ seed rate. The declining trend in grain number from highest seed rate $\left(200 \mathrm{~kg} \mathrm{ha}^{-1}\right)$ to lowest seed rate $\left(50 \mathrm{~kg} \mathrm{ha}^{-1}\right)$ in both sowing methods might be due to more competition between crop plants and weeds for light, air, moisture and nutrients. Ghaffar et al. (2013) and Naresh et al. (2014) communicated similar observations while working on wheat.

Biological yield is strongly interrelated with plant height and number of tillers per unit area. The data presented in Table 2 showed that seed rates and their interaction with sowing methods had a significant effect on biological yield, while sowing methods had a non significant effect on biological yield. The higher numerical values for biological yield were given by criss cross as compared to line sowing. The biological yield increased as the seed rate increased from $50 \mathrm{~kg}$ to $200 \mathrm{~kg} \mathrm{ha}^{-1}$. The seed rate interacted with two sowing methods and the maximum biological 
yield $\left(13.60 \mathrm{t} \mathrm{ha}^{-1}\right)$ was produced at $200 \mathrm{~kg} \mathrm{ha}^{-1}$ under criss cross sowing method, while the minimum biological yield $\left(8.3 \mathrm{~kg} \mathrm{ha}^{-1}\right)$ was realized in $50 \mathrm{~kg} \mathrm{ha}^{-1}$ involving line sowing. These results indicated that biological yield is associated with the number of tillers per $\mathrm{m}^{2}$, therefore at higher seeding rates, biological yield was maximum. Similar results were reported by Xue et al. (2011). Ghaffar et al. (2013) also found that planting geometry in wheat crop also affects the biomass and other yield components of wheat crop. Our findings are further supported by the work of Naresh et al. (2014) for biological yield of wheat.

The grain yield was determined by the cumulative effect of various yield components like number of spikes, grain weight and number of grains spike ${ }^{-1}$. Higher grain yield of wheat can be achieved by utilizing management system based on seed rates and sowing methods (Pandey and Kumar, 2005). The data presented in Table 2 exhibit that sowing methods, seed rates and their interaction had a significant effect on grain yield $P<0.05$. The highest mean grain yield $\left(5.65 \mathrm{t} \mathrm{ha}^{-1}\right)$ was noted in criss cross sowing method. In interaction, the maximum grain yield $\left(6.9\right.$ tha $\left.^{-1}\right)$ was recorded in criss cross sowing $\times 200 \mathrm{~kg}$ seed rate. It was however, statistically at par with criss cross planting @150 $\mathrm{kg} \mathrm{ha}^{-1}$. All seeding rates underline sowing yielded was lower as compared to criss cross planting under varying seed rates. It might be due to uniform emergence of a crop of seedling effectively combating weeds and the higher number of tillers produced under criss cross treatments. In our experiment, the use of $50 \mathrm{~kg}$ and $100 \mathrm{~kg}$ seed rate ha- ${ }^{-1}$ resulted in sub-optimal density vulnerable to weed competition, hence yielding lesser. At different seed rates, grain yield increased as seeding rate enhanced due to suppressive and smothering effect on weeds. Maximum grain yield was recorded at $200 \mathrm{~kg}$ seed ha ${ }^{-1}$ (Fig. 4). Panwar et al. (1995) also observed the excessive wheat yield in a criss cross by 0.44 tha $^{-1}$ compared with line sowing, while in their studies seed rates of 100 and $175 \mathrm{~kg} \mathrm{ha}^{-1}$ yielded 4.57 and $5.44 \mathrm{t}$ $\mathrm{ha}^{-1}$. Singh and Singh (1996) also harvested higher grain yield of wheat when the seed rate increased from 100 to $200 \mathrm{~kg} \mathrm{ha}^{-1 .}$ These results also agree with Hussain et al. (2010). They reported that increase in population rate up to a certain limit increase the grain yield in wheat crop. While, Kaur et al. (2014) observed $11 \%$ more grain yield in cross-drill method than unidirectional spacing, even in light soils under optimum fertilizers and irrigation conditions. Wiener et al. (2001) advocated more uniformity in criss cross (grid sowing) enabling better competition with weeds and higher grain yield in wheat. Subsequent studies of Kristensen et al. (2008) further confirmed the worth of grids planting and higher seeding rates on wheat with strong negative impact on weed growth.

The harvest index determines the inherent ability of a cultivar to convert the dry matter into economic yield. The data presented in Table 2 show that sowing methods, seed rates and their interaction had a non significant statistical effect on harvest index (\%). Ghaffar et al. (2013) reported that harvest index was not significantly affected by sowing methods and seed rates. It was observed that higher harvest index 54.4 was recorded under seed rate $150 \mathrm{~kg}$ seed rate $\mathrm{ha}^{-1} \mathrm{x}$ cross drill sowing methods. Singh et al. (2013) also found non-significant results among different sowing methods, but cross-drill sowing methods showed better results in this parameter over narrow row spacing. However, our findings are contradictory from Ali et al. (2010) who evaluated significant Harvest Index in such studies in wheat.

Cross-cross drill sowing $\left(30 \times 30 \mathrm{~cm}^{2}\right)$ proved promising method against weeds growth and development when wheat was planted at the highest seed rate $\left(200 \mathrm{~kg} \mathrm{ha}^{-1}\right)$. The spatial uniformity and in criss cross method rendered wheat crop more competitive with weeds and the smothering of weeds was more intensified at 150 and $200 \mathrm{~kg} \mathrm{ha}^{-1}$ seed rates. Highest number of tillers per $\mathrm{m}^{2}$ under higher seed rates and criss cross planting resulted in higher biological and straw yields in the present study. It is thus recommended that 150 to $200 \mathrm{~kg} \mathrm{ha}^{-1}$ seed rates coupled with criss cross planting may be adopted for effective weed competition and realizing bumper yields of spring wheat under Dera Ismail Khan, Pakistan conditions.

\section{Acknowledgment}

The authors would like to express their thanks to $\mathrm{Mr}$. Sender for linguistic improvement of the manuscript.

\section{References}

Ahmed, S., M. Salim and B.S. Chauhan: Effect of weed management and seed rate on crop growth under direct dry seeded rice systems in Bangladesh. PloS one, 9, e101919 (2014).

Ali, M., L. Ali, M. Sattar and M.A. Ali: Improvement in wheat (Triticum aestivum $\mathrm{L}$.) yield by manipulating seed rate and row spacing in Veharizone. J.Anim. Plant Sci., 20, 225-230 (2010).

Anonymous: Agriculture in Pakistan. Economic Survey, Ministry of Food, Agriculture and Livestock, Finance Division, Economic Advisor's Wing, Islamabad, p. 28. (2015)

Ashraf, M., M. Ozturk, M.S.A. Ahmad and A. Aksoy: Crop Production for Agricultural Improvement. Springer Science+Business Media, NY, p. 796 (2012).

Ayaz, S., P. Shah, H.M. Sharif and I. Ali: Yield, yield components and other important agronomic traits of wheat as affected by seed rate and planting geometry. Sarhad J. Agric., 15, 255-262 (1999).

Brac, A.S. and U.S. Walia: Weed dynamics and wheat productivity as influenced by planting techniques and weed control practices. Ind. J. Weed Sci., 41, 161-166 (2009).

Fahad, S., S. Hussain, B.S. Chauhan, S. Saud, C. Wu, S. Hassan, S. Tanveer, M. Jan and A.J. Huang: Weed growth and crop yield loss in wheat as influenced by row spacing and weed emergence times. Plant Prot., 71, 101-108 (2015).

Ghaffar, A., A. Mahmood, A. Yasir, N. Muhammad, T. Mahmood, M.K. Munir and A. Sattar: Optimizing seed rate and row spacing for different wheat cultivars. Crop Environ., 4, 11-18 (2013).

Hakeem, K.R., A. Parvaiz and M. Ozturk (Eds.): Crop Improvement-New Approaches and Modern Techniques. XXVII, Springer Science+Business Media, NY., p. 493 (2013). 
Hassan, G. and H. Khan: Effect of wild oats (Avena fatua L.) density on wheat yield and its components under varying nitrogen regimes. Pak. J. Bot., 39, 2585-2594 (2007).

Hussain, I., M.A. Khan and H. Khan: Effect of seed rates on the agrophysiological traits of wheat. Sarhad J. Agric., 26, 169-1761 (2010).

Kaur, J., G. Singh and A. Singh: Competitiveness of wheat cultivars under spacing and weed levels. Ind. J. Ecol., 41, 357-359 (2014).

Khan, H., M.A. Khan, I. Hussain and M.Z. Khan: Effect of sowing rates and methods on weed control and yield of wheat. Pak. J. Biol. Sci., 3, 829-832 (2000).

Khan, I., G. Hassan, M.I. Khan and M. Gul: Effect of wild oats (Avena fatua L.) and $\mathrm{N}$ levels on some agronomic traits of spring wheat (Tricticum aestivum L.). Turk J. Agric. For., 31, 91-101 (2007).

Khan, I.A., G. Hassan and K.B. Marwat: Interaction of wild oats (Avena fatua) with wheat (Triticum aestivum) seeded at different rates. Pak. J. Bot., 40, 1163-1167 (2008).

Korres, N.E. and R.J. Froud-Williams: Effects of winter wheat cultivars and seed rate on the biological characteristics of naturally occurring weed flora. Weed Res., 42, 417-428 (2002).

Kristensen, L., J. Olsen and J. Weiner: Crop density, sowing pattern, and nitrogen fertilization effects on weed suppression and yield in spring wheat. Weed Sci., 56, 97-102 (2008).

Mahajan, G., B.S. Chauhan and M.S. Gill: Dry seeded rice culture in Punjab state of India. A lesson Learned from farmers. Field Crops Res., 144, 89-99 (2013).

Marwat, K.B., M.A. Khan, S. Hashim, K. Nawab and A.M. Khattak: Integrated weed management in wheat. Pak. J. Bot., 43, 625-633 (2011).

Naresh, R.K., S. Tomar, S. Purushottam, S.P. Singh, D. Kumar, B. Pratap, V.A. Kumar and H. Nanher: Testing and evaluation of planting methods on wheat grain yield and yield contributing parameters in the irrigated agro-ecosystem of western Uttar
Pradesh, India. Afr. J. Agric. Res., 9, 176-182 (2014).

Pandey, D.K., K.S. Gangwar and S.K. Sharma: Effect of sowing techniques and weed control methods on weed growth performance of wheat (Triticum aestivum L.). Ann. Agric. Res. New Series, 30, 121-124 (2009).

Pandey, I.B. and K. Kumar: Response of wheat to seeding methods, and weed management, Ind. J. Agron., 50, 48-51 (2005).

Ross, M.A. and C.A. Lembi: Applied Weed Science McGraw-Hill Book Co. Inc., New York (1985).

Panwar, R.S., R.K. Malik, R.S. Balyan and D.P. Singh: Effect of isoproturon sowing method and seed rate on weeds and yield of wheat (Triticum aestivum). Ind. J.Agric. Sci., 65, 109-111 (1995).

Singh, B., A.K. Dhaka, R.K. Pannu and S. Kumar: Integrated weed management. A strategy for sustainable wheat production. Agric. Rev., 34, 243-255 (2013).

Singh, G. and O.P. Singh: Response of late-sown wheat (Triticum aestivum) to seeding methods and weed-control measures in flood-prone areas. Ind. J. Agron., 41, 237-41 (1996).

Steel, R.G.D., J.H. Torrie and D.A. Dickey: Principles and Procedures of statistics. A biometrical approach. $3^{\text {rd }}$ Eds.: McGraw Hill Co. Inc., New York, USA (1997).

Tunio, S.D., S.N. Kaka, A.D. Jarwar and M.R. Wagan: Effect of integrated weed management practices on wheat yield. Pak. J. Agric. Eng. Vet. Sci., 20, 5-10 (2004).

Weiner, J., H. Griepentrog and L. Kristensen: Suppression of weed by spring wheat Triticum aestivum increases with crop density and spatial uniformity. J. Appl. Ecol., 38, 784-790 (2001).

White, J.: The allometric interpretation of the self-thinning rule. J. Theor. Biol., 89, 475-500 (1981).

Xue, Q., A. Weiss, P.S. Baenziger and D.R. Shelton: Seeding rate and genotype affect yield and end use quality in winter wheat. $J$. Agron. Crop Sci., 2, 18-25 (2011). 